\title{
ENZYME VARIABILITY IN NATURAL POPULATIONS OF DAPHNIA MAGNA
}

\section{ECOLOGICAL DIFFERENTATION AND FREQUENCY CHANGES OF GENOTYPES AT AUDLEY END}

\author{
PAUL D. N. HEBERT* and ROBERT D. WARD $\dagger$ \\ Department of Genetics, University of Cambridge, Cambridge, England
}

Received 26.ix.75

\begin{abstract}
SUMMARY
Genotypic frequencies were analysed for two years in a permanent population of the cladoceran crustacean, Daphnia magna, which was polymorphic for an esterase and for malate dehydrogenase. Large temporal changes in genotypic frequencies occurred at both loci. There was no evidence of a seasonal pattern in the frequency changes. In most samples, genotypes at the two enzyme loci were non-randomly associated; these associations showed temporal changes. On some occasions marked spatial heterogeneity in genotypic frequencies existed within the population. Genotypic differences in parthenogenetic and sexual egg production were observed. In a primarily parthenogenetically reproducing population, non-random associations between genotypes at structural and regulatory loci will be the rule. The allozyme variants themselves may or may not be under selection. The relevance of these observations to ecological studies on Daphnia is considered.
\end{abstract}

\section{INTRODUGTION}

THE freshwater crustacean, Daphnia magna, reproduces by cyclical parthenogenesis. In temporary habitats which are filled with water for only short periods, populations are re-established each year from sexual eggs and reproduce parthenogenetically for two or at most three generations. In these populations genotypic frequencies at allozyme loci are generally in good agreement with Hardy-Weinberg expectations and temporal changes in frequencies are minor (Hebert, 1974a). However, in permanent habitats, where populations reproduce by continued parthenogenesis with only sporadic sexual recruitment, it has been shown that genotypic frequencies are very unstable and that Hardy-Weinberg disturbances are frequent (Hebert, 1974b). These previous studies on permanent populations have been short term, and the importance of seasonal changes in frequencies has not been examined. In the present study genotypic frequencies of the Audley End population were determined at two enzyme loci for 24 months. Large frequency changes were observed, but there was no evidence of a seasonal pattern. Heterogeneity of genotypic frequencies within the population was frequent but was not the cause of the major frequency changes.

* Present address: School of Biological Sciences, University of Sydney, Sydney, Australia. $\uparrow$ Present address: Dept. of Genetics, University College of Wales, Singleton Park, Swansea, U.K. 


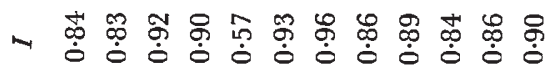

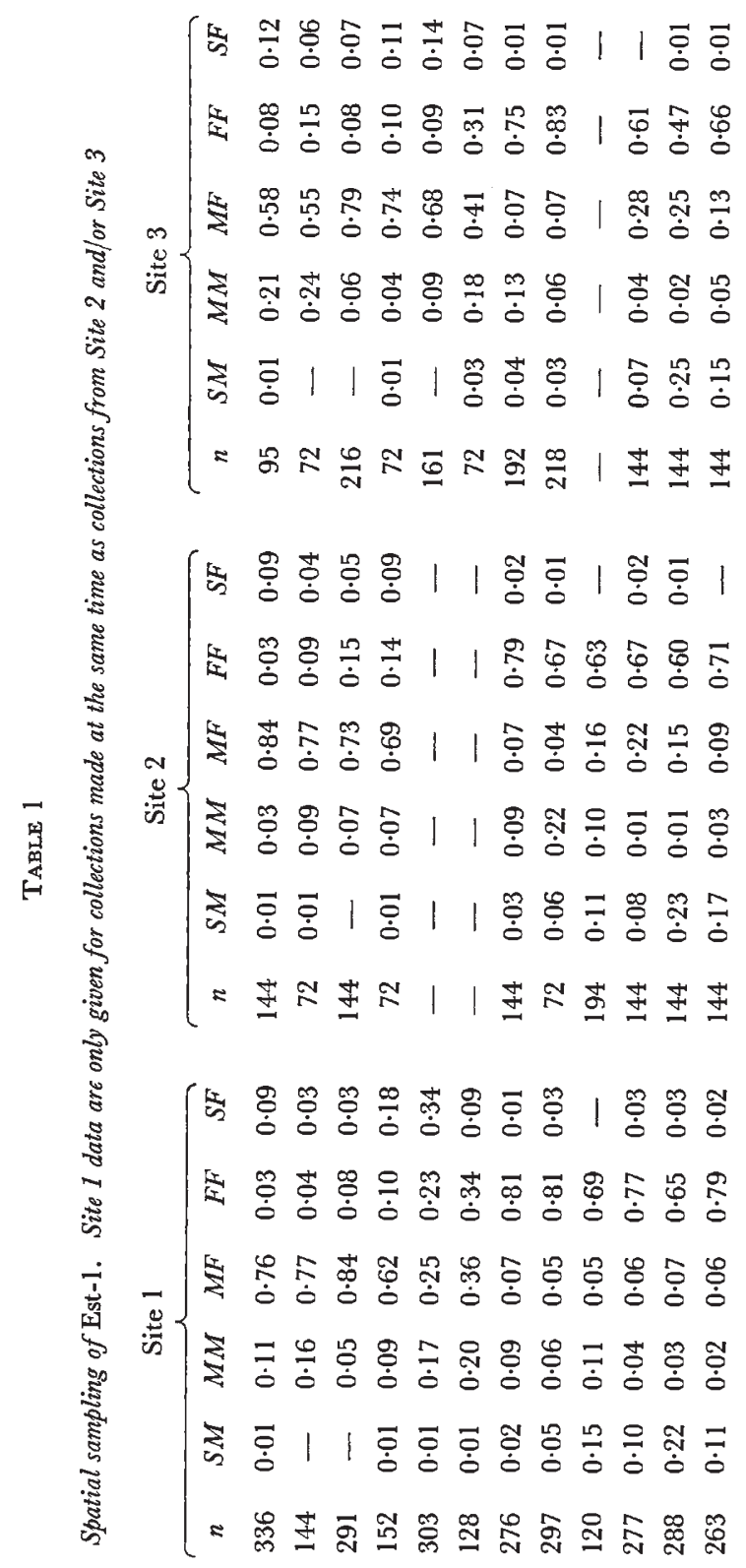

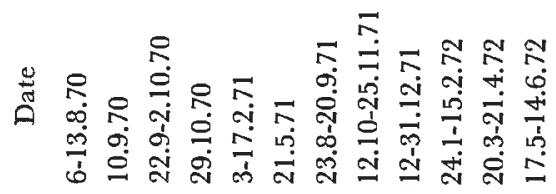


Non-random association of genotypes at the two loci was evident and temporal analysis indicated that these associations were flexible. Evidence of reproductive differences among genotypes was also obtained.

\section{MATERIALS AND METHODS}

The Audley End population inhabited a flooded gravel pit which was roughly circular with a diameter of 50 metres. Most of the pond was less than 1 metre deep, although a small central depression was nearly 3 metres in depth. Sampling was normally carried out in a strip 3 metres wide and 5 metres long on the western margin of the pond. Samples were collected every two weeks from July 1970 until July 1971 and thereafter once every four weeks until June 1972. Two additional sites were sampled less regularly. Site 2 was a similar sized strip along the middle of the northern margin, while Site 3 was along the eastern margin.

The population was polymorphic for two alleles of malate dehydrogenase $(M d h)$ and three alleles of esterase-1 (Est-1). Eleven other enzyme loci were monomorphic. Breeding experiments have confirmed the genetic interpretations of the allozyme patterns (Hebert and Ward, 1972). Genotypic frequencies in the present study are based on analyses of adult females. Individuals were ordinarily analysed for only a single enzyme, although associations between the two loci were determined by screening single individuals for both enzymes.

As a measure of the similarity of genotypic frequencies at different sites we use the index $I$ (Whittaker, 1960). The proportional similarity between two samples, $A$ and $B$, is

$$
I=1-0.5\left(\sum_{i}^{s}\left|a_{i}-b_{i}\right|\right),
$$

where $a_{i}$ is the proportion of the individuals in Sample A that belongs to genotype $i$, and $b_{i}$ is the proportion in Sample $\mathrm{B}$ belonging to genotype $i$; and there are $S$ genotypes. Complete similarity gives $I=1$ and complete dissimilarity gives $I=0$. In the present instance $\bar{I}$ is the mean of the three $I$ values obtained from the different pairwise combinations of frequencies from the three sites.

\section{RESUlts \\ (i) Esterase-1}

Large changes in genotypic frequencies were observed at Site 1 over the two-year sampling period (fig. 1) with the frequencies of both the $M F$ and $F F$ genotypes varying from less than 0.05 to about $0 \cdot 85$. Oscillations of a lesser magnitude were observed for the $M M, S M$ and $S F$ genotypes, whose frequencies varied from less than 0.01 in some samples to more than 0.20 in others. The $S S$ genotype was absent in all of the samples. The frequency changes do not show any obvious seasonal pattern; for instance, the frequency of the $F F$ genotype was 0.03 in September 1970 and 0.79 in September 1971.

Population size was not monitored, but some idea of its magnitude can be gained. The smallest sample analysed at Site 1 was $216(M d h+E s t-1$, August, 1971) and multiplying this number by the ratio of the total pond 
area $\left(c .2000 \mathrm{~m}^{2}\right) /$ area sampled $\left(15 \mathrm{~m}^{2}\right)$ gives a value of about 25,000 . There is good reason to suspect that this number is smaller than the actual minimum population size in so far as no attempt was made either to collect all the Daphnia in the sampling area or to analyse all the Daphnia collected. With such a large population size, random drift can be ruled out as a major factor in the frequency changes.

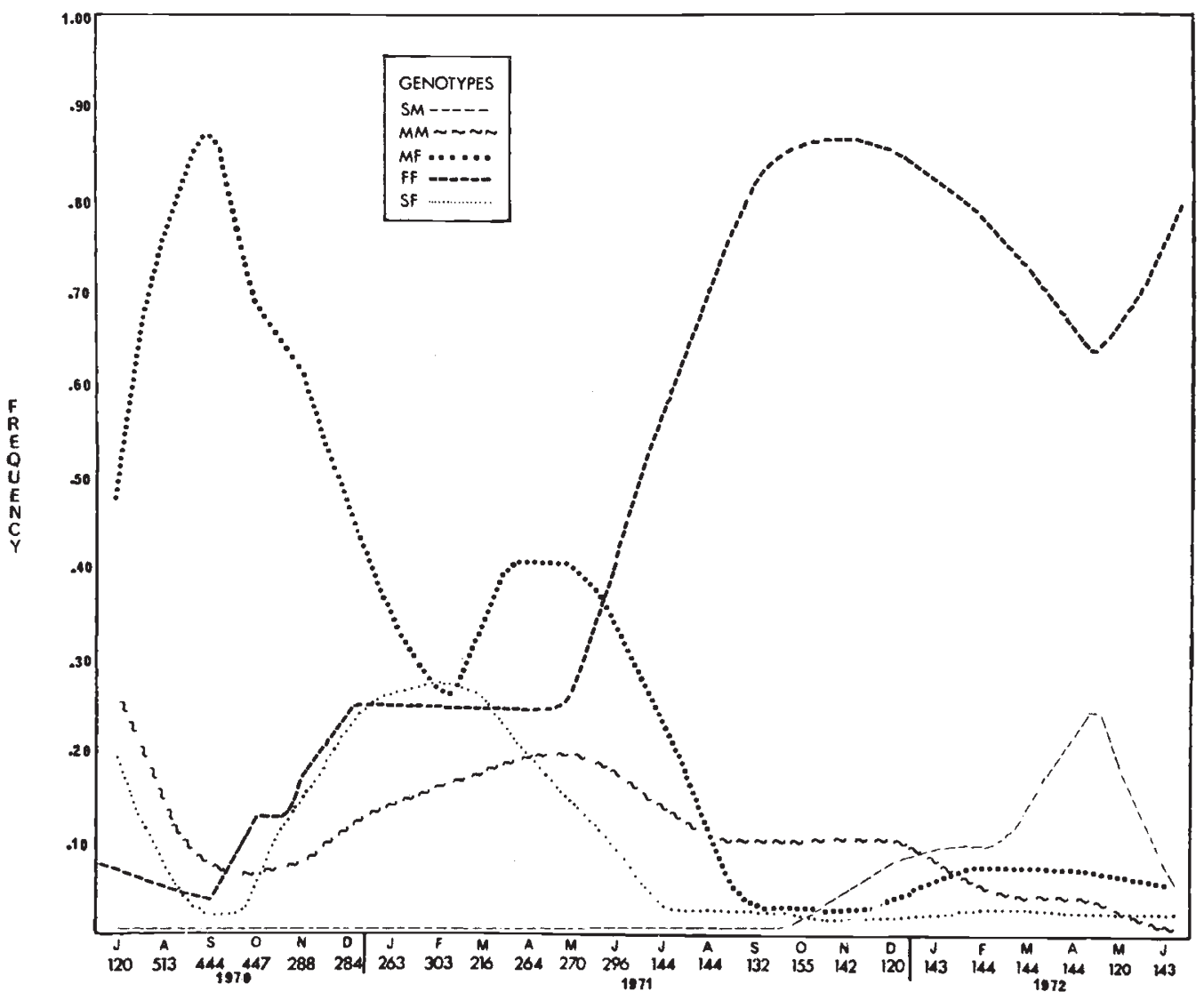

Frg. 1-Genotypic frequencies of Est-1 at Site 1. Collections were made three times a month during August, September and October 1970, twice a month from November 1970 to June 1971, and once a month for the remaining months. The actual points together with their standard errors are omitted for clarity, but the total sample sizes for each month are given.

Spatial sampling revealed that on some occasions genotypic frequencies were similar throughout the pond, while on other occasions there were marked differences. With the sample sizes used, similarity indices $(\bar{I})$ less than 0.90 generally indicate significant $(P<0.05)$ heterogeneity among the sites. Looking at the similarity indices over the two years there is evidence of recurrent differentiation and subsequent convergence of genotypic frequencies within the population. For instance, during both August $\left(\chi_{8}^{2}=30.6, \mathrm{P}<0.001\right)$ and early September $\left(\chi_{8}^{2}=20.7, \mathrm{P}<0.01\right) 1970$ significant spatial heterogeneity existed, but from late September $\left(\chi_{8}^{2}=12 \cdot 9\right.$, 
$\mathrm{P}>0 \cdot 10)$ until November $\left(\chi_{8}^{2}=7 \cdot 38, \mathrm{P}>0 \cdot 50\right)$ frequencies throughout the population were homogeneous. By February 1971 frequencies had diverged $\left(\chi_{4}^{2}=80.8, \mathrm{P}<0.001\right)$, but were again similar by May $\left(\chi_{4}^{2}=2.06, \mathrm{P}>0.70\right)$. Throughout the summer and autumn of 1971 parallel changes in frequency occurred at the three sites, but during late 1971 and early 1972 frequencies were again heterogeneous.

\section{(ii) Malate dehydrogenase}

When the population was first analysed for $M d h$ only heterozygotes were observed, but six months later $F F$ homozygotes were common (table 2),

TABLE 2

Frequency of the Mdh-MF genotype. Only one MM individual was observed (Site 1, fune 1971) so FF frequency is 1.00-MF frequency

\begin{tabular}{|c|c|c|c|c|c|c|c|}
\hline \multirow[b]{2}{*}{ Date } & \multicolumn{2}{|c|}{ Site 1} & \multicolumn{2}{|c|}{ Site 2} & \multicolumn{2}{|c|}{ Site 3} & \\
\hline & $n$ & $M F$ & $n$ & $M F$ & $n$ & $M F$ & $I$ \\
\hline 13.8.70 & 72 & 1.00 & - & - & - & - & - \\
\hline 17.2 .71 & 120 & $0 \cdot 62$ & - & - & - & - & - \\
\hline 10.3 .71 & 200 & 0.56 & - & - & - & - & - \\
\hline $5-19.4 .71$ & 288 & 0.45 & - & - & - & - & - \\
\hline $13-21.5 .71$ & 262 & $0 \cdot 42$ & - & - & - & - & - \\
\hline $7-23.6 .71$ & 288 & $0 \cdot 25$ & - & - & - & - & - \\
\hline 12.7 .71 & 144 & $0 \cdot 29$ & - & - & - & - & - \\
\hline 23.8.71 & 72 & 0.06 & 72 & $0 \cdot 02$ & 72 & $0 \cdot 02$ & 0.97 \\
\hline 20.9 .71 & 142 & 0.08 & 72 & $0 \cdot 10$ & 96 & $0 \cdot 15$ & 0.95 \\
\hline 12.10 .71 & 120 & $0 \cdot 06$ & 72 & $0 \cdot 04$ & - & - & 0.98 \\
\hline 8.11 .71 & 96 & $0 \cdot 04$ & 72 & $0 \cdot 09$ & 221 & $0 \cdot 12$ & 0.96 \\
\hline $13-31.12 .71$ & 192 & $0 \cdot 09$ & 167 & $0 \cdot 17$ & 144 & 0.08 & 0.93 \\
\hline 24.1 .72 & 96 & $0 \cdot 13$ & 72 & 0.44 & 72 & 0.33 & 0.79 \\
\hline 15.2 .72 & 120 & $0 \cdot 06$ & 72 & $0 \cdot 15$ & 72 & 0.23 & 0.89 \\
\hline 20.3.72 & 96 & $0 \cdot 10$ & 72 & $0 \cdot 14$ & 96 & 0.27 & 0.88 \\
\hline 21.4 .72 & 120 & $0 \cdot 06$ & 72 & $0 \cdot 11$ & 71 & $0 \cdot 24$ & 0.88 \\
\hline 17.5 .72 & 119 & 0.07 & 72 & 0.05 & 72 & 0.21 & 0.89 \\
\hline 14.6 .72 & 144 & 0.04 & 71 & $0 \cdot 08$ & 72 & $0 \cdot 12$ & 0.9 \\
\hline
\end{tabular}

having increased from a frequency of less than $0 \cdot 01$ to almost $0 \cdot 40$. The FF genotype continued to increase in frequency until it reached a value of 0.94 in August 1971, where it remained stabilised for the rest of the study. Genotypic frequencies in the other sampling areas were similar to those at Site 1 during late 1971 and in June 1972, but in early $1972 \bar{I}$ values were low due to the higher frequency of $M F$ heterozygotes at Sites 2 and 3.

\section{(iii) Association between Est-1 and Mdh genotypes}

Throughout the study the $M F$ genotype of Est-1 at Site 1 was almost always associated with the $M d h-M F$ genotype (fig. 2). In August 1970, since all screened individuals had the $M d h-M F$ genotype, the other $E_{s t-1}$ genotypes were also completely associated with this genotype, but in later samples an increasingly large proportion of the non-MF Est-1 individuals was associated with the $M d h-F F$ genotype. Partitioned $\chi^{2}$ analysis of the March and September 1971 data (table 3) indicates a significant increase 


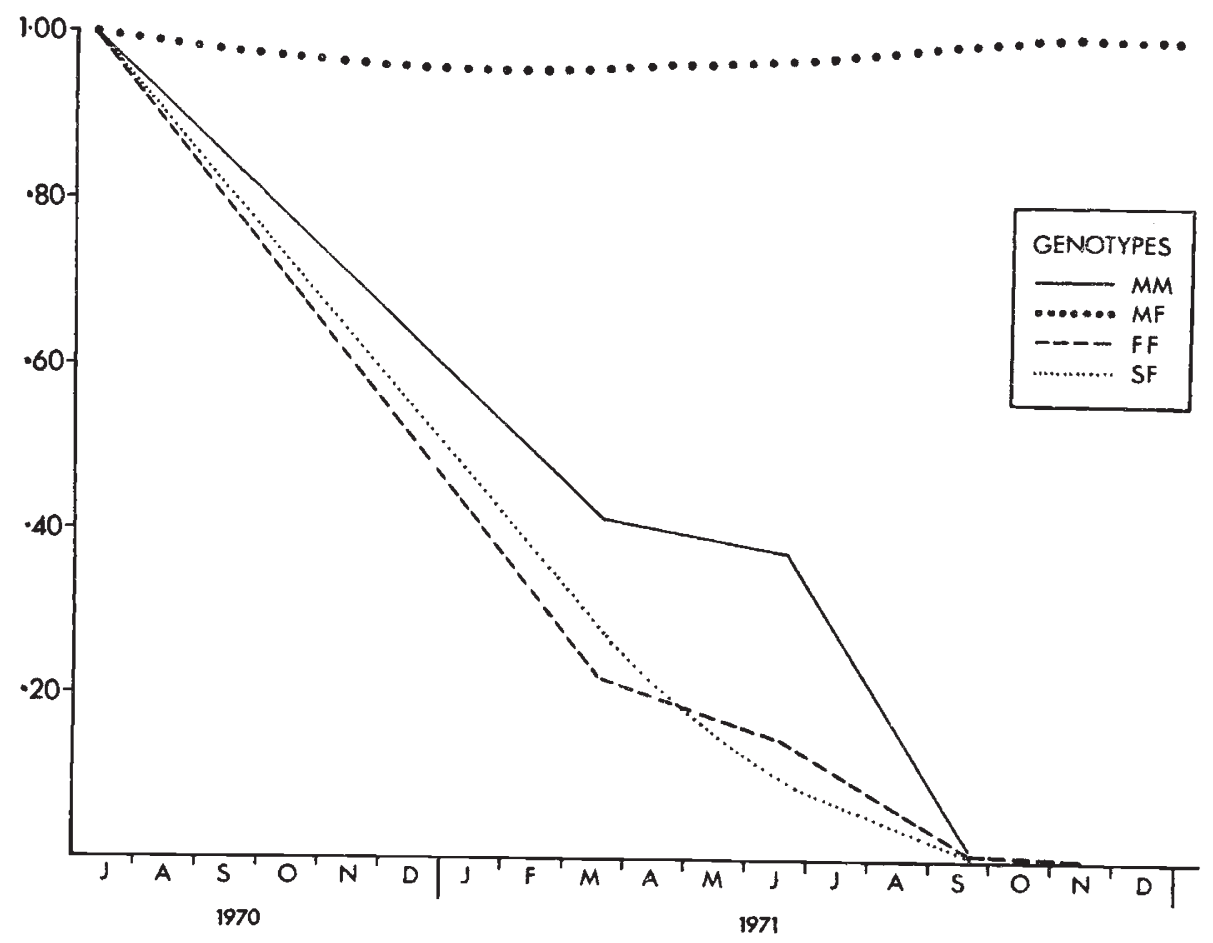

FIG. 2-Proportion of each Est-1 genotype associated with the $M d h-M F$ genotype.

TABLE 3

Analysis of the association between $\mathrm{Est}-1$ and $\mathrm{Mdh}$ genotypes at Site 1 using a partitioned $\chi^{2}$ analysis

(a) Genotypic frequencies

Est-1 $\left\{\begin{array}{lrrrr}S M & \overbrace{M F}^{S .3 .71} & & \overbrace{M F}^{20.9 .71} \\ M M & 0 & 1 & 0 & 10 \\ M F & 64 & 18 & 0 & 7 \\ F F & 4 & 14 & 16 & 0 \\ S F & 9 & 26 & 0 & 3\end{array}\right.$

(b) Analysis

$\begin{array}{lcrc}\quad \text { Component } & \chi^{2} & \text { d.f. } & \text { P } \\ \text { Total } & 519.37 & 13 & <0.001 \\ M d h \times \text { Est-1 } & 223.47 & 4 & <0.001 \\ \text { Dates } \times \text { Est }-1 & 175.09 & 4 & <0.001 \\ \text { Dates } \times \text { Mdh } & 106.75 & 1 & <0.001 \\ \text { Dates } \times \text { Mdh } \times \text { Est-1 } & 14.06 & 4 & <0.01\end{array}$


in the imbalance between the dates $(P<0.01)$ after the effects of changes in genotypic frequencies at the individual loci have been removed. It is likely that these associations of genotypes existed throughout the pond, because the frequencies of the $M F$ genotypes at both loci were similar in all samples (tables 1 and 2).

\section{(iv) Sexual egg formation}

Sexual females were observed at Audley End only during August 1970 and May 1971 and on both occasions less than 3 per cent of the adult females were carrying sexual eggs. It is worth stressing that the same female can produce both sexual and parthenogenetic eggs and that no sequential rigor is placed on this ability.

Genotypic frequencies among females with sexual eggs were markedly different from those in non-sexual females (table 4). At Site 1 during

TABLE 4

Est-1 frequencies among sexual and non-sexual females

\begin{tabular}{|c|c|c|c|c|c|c|c|c|c|c|c|c|c|}
\hline Date & Site & $n$ & $S M$ & $M M$ & $M F$ & $F F$ & $S F$ & $n$ & $S M$ & $M M$ & $M F$ & $F F$ & $S F$ \\
\hline 13.8 .70 & 1 & 33 & - & 0.58 & $0 \cdot 30$ & 0.09 & 0.03 & 144 & - & $0 \cdot 14$ & 0.78 & 0.04 & 0.04 \\
\hline 13.8 .70 & 3 & 27 & - & 0.41 & 0.48 & 0.04 & 0.07 & 92 & - & 0.22 & 0.57 & 0.09 & $0 \cdot 12$ \\
\hline 13.5 .71 & 1 & 44 & 0.02 & 0.42 & $0 \cdot 38$ & 0.08 & $0 \cdot 10$ & 132 & 0.02 & 0.17 & 0.41 & $0 \cdot 26$ & $0 \cdot 14$ \\
\hline
\end{tabular}

August 1970 the $M M$ genotype of Est-1 was more frequent among sexual than non-sexual females $\left(\chi_{1}^{2}=29.83, \mathrm{P}<0.001\right)$ while the $M F$ genotype was underrepresented among sexual females $\left(\chi_{1}^{2}=31 \cdot 66, \mathrm{P}<0.001\right)$. Similar trends were observed at Site 3. In 1971 the $M M$ genotype was again more frequent among the sexual females $\left(\chi_{1}^{2}=11 \cdot 04, \mathrm{P}<0.001\right)$, while the $F F$ genotype was underrepresented $\left(\chi_{1}^{2}=5.41, \mathrm{P}<0.025\right)$.

\section{(v) Parthenogenetic egg production}

Genotypic differences in parthenogenetic egg production were frequently observed (table 5). For instance, during August 1970, the $M F$ genotype of Est-1 was more frequent among females carrying three or more embryos than among females with one or two embryos $\left(\chi_{1}^{2}=4.49, \mathrm{P}<0.05\right)$, which in turn had a higher proportion of the $M F$ genotype than females without embryos $\left(\chi_{1}^{2}=5 \cdot 72, \mathrm{P}<0 \cdot 025\right)$. The mean number of embryos carried by $M F$ individuals was, at this time, significantly greater than that carried by any of the other genotypes. In contrast, during February 1971, the $M F$ genotype was much more common among non-reproductive than reproductive females, and the $M M$ and $S F$ genotypes were carrying the greatest number of embryos per individual. In both these instances the females without parthenogenetic eggs were mature; their non-reproductive state was apparently due to an inability to collect sufficient food resources to enable egg production. The direct relationship between food availability and brood size in Daphnia has been documented on many occasions (Slobodkin, 1954; Hall, 1964). 
TABLE 5

Reproductive differences between Est-1 genotypes at Site 1

(a) Genotypic frequencies

\begin{tabular}{|c|c|c|c|c|c|c|c|}
\hline \multirow[b]{2}{*}{ Date } & \multirow{2}{*}{$\begin{array}{l}\text { Eggs } \\
\text { carried }\end{array}$} & \multicolumn{6}{|c|}{ Genotypic frequency } \\
\hline & & $n$ & $S M$ & $M M$ & $M F$ & $F F$ & $S F$ \\
\hline $\begin{array}{l}\text { August } \\
1970\end{array}$ & $\left\{\begin{array}{l}0 \\
1 \text { or } 2 \\
3 \text { or } 4\end{array}\right.$ & $\begin{array}{l}163 \\
143 \\
100\end{array}$ & $\begin{array}{l}0.01 \\
0.01 \\
-\end{array}$ & $\begin{array}{l}0 \cdot 13 \\
0 \cdot 06 \\
0 \cdot 05\end{array}$ & $\begin{array}{l}0 \cdot 74 \\
0 \cdot 85 \\
0 \cdot 94\end{array}$ & $\begin{array}{l}0 \cdot 04 \\
0 \cdot 05 \\
0 \cdot 01\end{array}$ & $\begin{array}{c}0.07 \\
0.03 \\
-\end{array}$ \\
\hline $\begin{array}{c}\text { February } \\
1970 \dagger\end{array}$ & $\left\{\begin{array}{l}0 \\
1-3 \\
4-6 \\
7-9\end{array}\right.$ & $\begin{array}{r}281 \\
79 \\
72 \\
29\end{array}$ & $\begin{array}{l}- \\
-\end{array}$ & $\begin{array}{l}0 \cdot 17 \\
0 \cdot 31 \\
0 \cdot 26 \\
0 \cdot 22\end{array}$ & $\begin{array}{l}0.25 \\
0.07 \\
0.06 \\
0.08\end{array}$ & $\begin{array}{l}0 \cdot 24 \\
0 \cdot 10 \\
0 \cdot 06 \\
0 \cdot 03\end{array}$ & $\begin{array}{l}0.34 \\
0.52 \\
0 \cdot 61 \\
0.67\end{array}$ \\
\hline
\end{tabular}

(b) Mean number embryos/individual ( \pm S.E.)

Date

August 1970

February $1970 \ddagger$

\begin{tabular}{ccccc}
\hline$S M$ & $M M$ & $M F$ & $F F$ & $S F$ \\
$0 \cdot 67 \pm 0 \cdot 67$ & $0 \cdot 80 \pm 0 \cdot 19$ & $1 \cdot 53 \pm 0 \cdot 07$ & $1 \cdot 00 \pm 0 \cdot 26$ & $0 \cdot 31 \pm 0 \cdot 15$ \\
- & $0 \cdot 43 \pm 0.07$ & $0 \cdot 08 \pm 0 \cdot 03$ & $0 \cdot 09 \pm 0.03$ & $0.52 \pm 0.05$
\end{tabular}

$\uparrow$ Only 22 reproductive 's were present among 303 individuals selected randomly, so an additional subsample of 158 reproductive individuals was selected.

\$Values corrected for non-randomly selected reproductives.

\section{TABLE 6}

Frequency of the Mdh MF genotype among reproductive $(R)$ and non-reproductive (N.R.) females

\begin{tabular}{|c|c|c|c|c|c|c|c|}
\hline \multirow[b]{2}{*}{ Date } & \multirow[b]{2}{*}{ Class } & \multicolumn{2}{|c|}{ Site 1} & \multicolumn{2}{|c|}{ Site 2} & \multicolumn{2}{|c|}{ Site 3} \\
\hline & & $n$ & $M F$ & $n$ & $M F$ & $n$ & $M F$ \\
\hline 8.10 .71 & $\begin{array}{l}\text { N.R. } \\
\text { R. }\end{array}$ & $\begin{array}{l}52 \\
44\end{array}$ & $\begin{array}{l}0.04 \\
0.04\end{array}$ & $\overline{-}$ & 二 & $\begin{array}{l}43 \\
53\end{array}$ & $\begin{array}{l}0.09 \\
0 \cdot 10\end{array}$ \\
\hline 25.11 .71 & $\begin{array}{l}\text { N.R. } \\
\text { R. }\end{array}$ & $\begin{array}{l}41 \\
31\end{array}$ & $\begin{array}{l}0 \cdot 09 \\
0 \cdot 04\end{array}$ & $\begin{array}{l}37 \\
35\end{array}$ & $\begin{array}{l}0 \cdot 07 \\
0 \cdot 11\end{array}$ & $\begin{array}{l}59 \\
66\end{array}$ & $\begin{array}{l}0.08 \\
0 \cdot 11\end{array}$ \\
\hline 13.12 .71 & $\begin{array}{l}\text { N.R. } \\
\text { R. }\end{array}$ & $\begin{array}{r}112 \\
48\end{array}$ & $\begin{array}{l}0 \cdot 11 \\
0 \cdot 07\end{array}$ & $\begin{array}{l}62 \\
34\end{array}$ & $\begin{array}{l}0 \cdot 06 \\
0 \cdot 76\end{array}$ & $\begin{array}{l}65 \\
31\end{array}$ & $\begin{array}{l}0.07 \\
0.69\end{array}$ \\
\hline 31.12 .71 & $\begin{array}{l}\text { N.R. } \\
\text { R. }\end{array}$ & $\begin{array}{l}60 \\
32\end{array}$ & $\begin{array}{l}0 \cdot 07 \\
0 \cdot 08\end{array}$ & $\begin{array}{l}72 \\
33\end{array}$ & $\begin{array}{l}0 \cdot 13 \\
0 \cdot 73\end{array}$ & $\begin{array}{l}62 \\
40\end{array}$ & $\begin{array}{l}0.09 \\
0.71\end{array}$ \\
\hline 24.1.72 & $\begin{array}{l}\text { N.R. } \\
\text { R. }\end{array}$ & $\begin{array}{l}95 \\
25\end{array}$ & $\begin{array}{l}0 \cdot 07 \\
0 \cdot 44\end{array}$ & $\begin{array}{l}77 \\
67\end{array}$ & $\begin{array}{l}0 \cdot 10 \\
0 \cdot 76\end{array}$ & $\begin{array}{l}96 \\
48\end{array}$ & $\begin{array}{l}0.08 \\
0.69\end{array}$ \\
\hline 15.2.72 & $\begin{array}{l}\text { N.R. } \\
\text { R. }\end{array}$ & $\begin{array}{r}132 \\
18\end{array}$ & $\begin{array}{l}0 \cdot 05 \\
0 \cdot 28\end{array}$ & $\begin{array}{r}102 \\
17\end{array}$ & $\begin{array}{l}0 \cdot 06 \\
0 \cdot 41\end{array}$ & $\begin{array}{r}103 \\
41\end{array}$ & $\begin{array}{l}0 \cdot 13 \\
0.63\end{array}$ \\
\hline 20.3.72 & $\begin{array}{l}\text { N.R. } \\
\text { R. }\end{array}$ & $\begin{array}{r}16 \\
128\end{array}$ & $\begin{array}{l}0 \cdot 06 \\
0 \cdot 10\end{array}$ & $\begin{array}{l}12 \\
60\end{array}$ & $\begin{array}{l}0 \cdot 00 \\
0 \cdot 15\end{array}$ & - & 二 \\
\hline 21.4 .72 & $\begin{array}{l}\text { N.R. } \\
\text { R. }\end{array}$ & $\begin{array}{r}24 \\
120\end{array}$ & $\begin{array}{l}0.00 \\
0 \cdot 07\end{array}$ & $\begin{array}{r}26 \\
118\end{array}$ & $\begin{array}{l}0 \cdot 12 \\
0 \cdot 14\end{array}$ & $\begin{array}{r}22 \\
122\end{array}$ & $\begin{array}{l}0 \cdot 18 \\
0 \cdot 31\end{array}$ \\
\hline
\end{tabular}




\section{(vi) Spatial analysis of egg production}

Samples were analysed at the three sites from November 1971 until April 1972 to determine if there were site related differences in egg production between the two $M d h$ genotypes. Each sample was divided into reproductive and non-reproductive females, and the reproductive females were subdivided on the basis of egg numbers.

The proportion of reproductive females varied from one month to another, presumably as a result of fluctuating food levels and temperatures, but differences between sites were minor. During October and November about 40 per cent of the females at each site were reproductive, but from December until February only 10 per cent of the females had eggs. During March and April 80 per cent of the females were reproductive. During the winter supplementary samples of reproductive females were collected to ensure adequate sample sizes.

Analysis of reproductive females over the six months failed to reveal any differences in brood size between the two $M d h$ genotypes. In addition, during October and November genotypic frequencies were similar among the reproductive and non-reproductive females at each of the sites (table 6). This relationship was maintained at Site 1 during December, but at Sites 2 and 3 the $M F$ genotype was 10 times more frequent among reproductive than non-reproductive females. During January and February $M F$ heterozygotes were 5-7 times as frequent among the reproductive females at all three sites, but during March and April this difference disappeared at all of the sites.

\section{Discussion}

Large changes in the genetic composition of the Audley End population occurred during the sampling period, as genotypes which were rare at each of the sampling sites subsequently became abundant and vice versa. Natural selection was almost certainly responsible for most changes although some of the rapid, relatively small changes in frequency were probably due to the movement of individuals within the pond. For example, the increase in frequency of the $M F$ genotype of Est-1 at Site 1 from 0.25 in February 1971 to 0.40 one month later may well have been the result of immigration from Site 3 where $M F$ frequency was $0 \cdot 65$. In this particular instance it seemed as if the entire Audley End population was mixed, for $M F$ frequency declined at Site 3 to a value close to the new frequency at Site 1 . This was not an isolated instance; there seemed to be a recurrent pattern of differentiation and subsequent convergence of Est-1 genotypic frequencies thoughout the pond. The local differentiation presumably results from selective differences within the pond coupled with little migration, while wind mixing of the population could be the cause of the sudden returns to uniformity (Stommel, 1949; George and Edwards, 1973). As such marked spatial heterogeneity has not been observed in any other Daphnia populations (Hebert, 1972, 1974c) it seems worth while considering why it occurred at Audley End. The most important factor was probably pond size, for the Audley End pond has a surface area about 25 times that of the other habitats in which $D$. magna has been studied. As the Audley End pond is itself small when compared with a freshwater lake, it seems likely that subpopulation differentiation will be a major factor to consider in studies on lacustrine Daphnia. 
Parthenogenesis in D. magna is ameiotic (Mortimer, 1936; Hebert and Ward, 1972), and in a primarily parthenogenetic population non-random associations between loci are to be expected. Indeed, the association between the Est-1 and $M d h$ genotypes makes it clear that the apparent selective differences between allozyme genotypes are actually based on genetic differences at many loci in linkage disequilibrium. The present data cannot be interpreted as implying that the enzyme variants themselves are under selection. However, favourable epistatic interactions between loci that are being maintained by selection can be preserved indefinitely. The flexibility of linkage associations at Audley End, as revealed by the changing associations between genotypes at the two enzyme loci, contrasts with the situation in the population of D. magna at Moulton (Hebert, 1974b), where it seemed that the resident parthenogenetic population consisted of only a single genotype which was heterozygous at the two enzyme loci analysed. This difference may be related to the length of time the two populations have been established. The Audley End pit had only been flooded for about 15 years whereas the Moulton pond was much older. Perhaps the Moulton population also passed through a phase of "genotypic exploration" shortly after it was founded. Alternatively, this difference between the populations could be an effect of increased environmental heterogeneity associated with the larger size of the Audley End habitat.

Genotypic differences in parthenogenetic and sexual egg production were frequently observed at Audley End. In some cases up to tenfold differences in egg production existed between different genotypes at a given site, while on other occasions differences of a similar magnitude were observed between individuals of one genotype in different areas of the pond. Attempts to correlate genotypic differences in parthenogenetic egg production with changes in genotypic frequencies met with little success; perhaps due to the inadequacies in the present data rather than the non-existence of such a relationship. Thorough investigation requires co-ordinate studies on population density, genotypic frequencies and genotypic egg productions at several sites within the pond.

Our data do make it clear, however, that reproductive phenotype in Daphnia is affected both by genetic and environmental factors. Yet experimental studies of factors affecting sexual egg production (Stross and Hill, 1965; Stross, 1966) and parthenogenetic egg production (Slobodkin, 1954; Green, 1954; Frank, Boll and Kelly, 1957) have concentrated entirely on the latter, the work having been carried out on genetically uniform clones. Moreover, these sorts of studies have been widely used to interpret observations made on natural populations (Slobodkin, 1954; Hall, 1964; Dodson, 1972).

The present study makes it clear, however, that for natural population studies, a systematic attempt must be made to gauge the extent of genotypic diversity in developmental rate and progeny production using a variety of food sources in place of the conventional single clone studies on a single food source. Such studies would undoubtedly lead to a better understanding of Daphnia ecology and might additionally resolve whether the genetic instability of permanent populations of Daphnia results from the synthesis of novel, adaptively superior genotypes or the readjustment of existing genotypic frequencies due to environmental change. 


\section{REFERENCES}

Dodson, s. J. 1972. Mortality in a population of Daphnia rosea. Ecology, 53, 1011-1023. FRANK, P. W., BOLL, C. D., AND KELLY, R. w. 1957. Vital statistics of laboratory cultures of Daphnia pulex De Geer as related to density. Physiol. Zool., 30, 287-305.

GEORGE, D. G. AND EDWARDS, R. W. 1973. Daphnia distribution within Langmuir circulations. Limnol. Oceanogra, 18, 798-800.

GreEn, J. 1954. Growth, size and reproduction in Daphnia magna. Proc. Zool. Soc. Lond., $126,173-204$.

HALL, D. J. 1964. An experimental approach to the dynamics of a natural population of Daphnia galeata mendotae. Ecology, 45, 94-112.

HEBERT, P. D. N. 1972. Enzyme variability in natural populations of Daphnia magna. Ph.D. thesis, Cambridge University.

HEBERT, P. D. N. 1974a. Enzyme variability in natural populations of Daphnia magna. III. Genotypic frequencies in temporary populations. Genetics, 77, 335-341.

HEBERT, P. D. N. 1974b. Enzyme variability in natural populations of Daphnia magna. II. Genotypic frequencies in permanent populations. Genetics, 77, 323-334.

HEBERT, P. D. N. 1974c. Ecological differences between genotypes in a natural population of Daphnia magna. Heredity, 33, 327-337.

HEBERT, P. D. N., AND WARD, R. D. 1972. Inheritance during parthenogenesis in Daphnia magna. Genetics, 71, 639-642.

MORTIMER, C. H. 1936. Experimentelle und cytologische Untersuchungen uber den Generationswechel der Cladoceran. Zool. F. b. Physiol., 56, 323-388.

slobodkin, L. B. 1954. Population dynamics in Daphnia obtusa Kutz. Ecol. Monogr., 24, 69-88.

STOMmel, H. 1949. Trajectories of small bodies sinking slowly through convection cells. 7. Mar. Res., 8, 24-29.

STROSs, R. G. 1966. Light and temperature requirements for diapause development and release in Daphnia. Ecology, 47, 368-374.

stross, R. G., AND HILl, J. G. 1965. Diapause induction in Daphnia requires two stimuli. Science, 150, 1462-1464.

WhitTAKeR, R. H. 1960 . Vegetation of the Siskiyou mountains, Oregon and California. Ecol. Monogr., 30, 279-338. 